\title{
ANALISIS KELAYAKAN KEGRAFIKAAN BUKU TEMATIK KELAS III SEKOLAH DASAR
}

\author{
Setiya Budi Wulyandari ${ }^{1^{*}}$ \\ Dedy Irawan ${ }^{2}$ \\ ${ }^{1,2,3}$ Prodi Pendidikan Guru Sekolah Dasar, Universitas Muhammadiyah \\ Purwokerto, Indonesia \\ setivabudiwulyandari024@gmail.com ${ }^{1 *}$
}

\begin{abstract}
Abstrak
Penelitian ini bertujuan untuk mengetahui bagaimana kelayakan kegrafikan pada buku teks kelas III SD. Jenis penelitian ini adalah jenis penelitian kualitatif. Penelitian ini dilaksanakan di SD Negeri 1 Purbalingga Lor, SD Negeri 2 Purbalingga Lor, SD Negeri 2 Wirasa, SD Negeri 1 Purbalingga Kidul, MI Muhammadiyah Cabang, MI Muhammadiyah Wirasana, MI Muhammdaiyah Pesayangan, MI Istiqomah Sambas, dan MI Kalikabong pada bulan Mei 2021. Sumber data yang digunakan pada penelitian ini yaitu data primer dan data sekunder. Data primernya berupa buku teks pelajaran pada kelas III dan data sekunder yang berupa kajian pustaka untuk melengkapi data primer. Teknik pengumpulan data pada penelitian ini yaitu menggunakan Teknik observasi, analisis teks dan studi Pustaka. Analisis data yang digunakan pada penelitian ini menggunakan komponen Miles dan Huberman yang terdiri dari reduksi data, penyajian data dan verifikasi data. Penelitian ini menggunakan triangulasi teknik untuk mengukur keabsahan data. Berdasarkan hasil analisis yang dilakukan, hasil penelitian ini menunjukkan bahwa bahwa Buku Tematik Terpadu Kurikulum 2013 Tema 8 "Praja Muda Karana", Cemara Tema 8 "Praja Muda Karana" 3b semester 2, Buku Pengayaan Tema 8 "Praja Muda Karana" Semester Genap, Buku Forum Tema 4 "Kewajiban dan Hakku" Semester Ganjil dan Buku Tematik Tema 7 "Perkembangan Teknologi" sudah sesuai dengan kriteria kelayakan buku teks.
\end{abstract}

Kata Kunci: Buku Teks Tematik, Kelayakan Kegrafikan, Sekolah Dasar.

Published by:

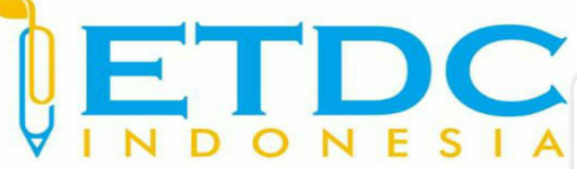

Copyright (C) 2021 The Author (s)

This article is licensed under CC BY 4.0 License

\section{(cc) $\mathrm{BY}$}




\section{ANALISIS KELAYAKAN KEGRAFIKAAN BUKU TEMATIK KELAS III SEKOLAH DASAR}

\section{Pendahuluan}

Kemajuan teknologi dan kesadaran menuntut ilmu agar terciptanya masyarakat yang aktif belajar. Sekolah merupakan Lembaga yang digunakan untuk menuntut ilmu. Sistem belajar mengajar selalu mengaitkan dengan membaca, maka dari itu membaca sangatlah penting dalam pembelajaran. Hadini (2017: 20) mengatakan bahwa membaca merupakan suatu kegiatan untuk mendapatkan pengetahuan dan informasi. Kepandaian membaca pada biasanya diperoleh dari sekolah. Kepandaian membaca ini merupakan suatu keterampilan yang sangat unik serta berperan penting bagi perkembangan ilmu pengetahuan dan untuk alat komunikasi bagi kehidupan setiap manusia.

Mata pelajaran bahasa dan sastra Indonesia adalah salah satu rencana yang telah direncanakan secara tertentu untuk bimbingan siswa supaya dapat memiliki kemampuan membaca. Implementasi pembelajaran membaca yang pantas akan memudahkan guru dalam pengembangan kemampuan membaca siswa dan memperbaiki mutu pembelajaran membaca. Usaha lain yang dapat meningkatkan mutu pembelajaran membaca yaitu dengan menyajikan bahan ajar berupa buku teks pelajaran. Buku teks mempunyai kedudukan dan fungsi yang penting dalam pembelajaran di sekolah. Hal ini sependapat dengan Asri (2017: 115) yang mengatakan bahwa salah satu aspek yang memiliki peranan penting dalam pembelajaran di sekolah adalah keberadaan buku teks. Buku teks berfungsi menjadi penunjang guru dala proses pembelajaran, buku teks juga merupakan salah satu akar pengetahuan bagi siswa.

Buku teks merupakan sumber pengetahuan untuk peserta didik dan juga buku pegangan untuk guru agar dapat menyampaikan materi pembelajaran sesuai dengan kurikulum yang berlaku. Asri (2017: 71) mengatakan bahwa buku teks pelajaran merupakan salah satu media pembelajaran. Sebagai salah satu media pembelajaran buku teks pelajaran memiliki beberapa fungsi.

Buku teks mempunyai kualitas yang berbeda antara buku teks satu dengan buku teks yang lain, diantaranya ada buku teks yang mempunyai kualitas tinggi dan sebaliknya. Oleh karena itu, pengguna buku teks seperti pendidik harus bisa memilih dan menentukan mana buku yang mempunyai kualitas tinggi dan mana 
yang tidak mempunyai kualitas. Kualitas buku teks dapat dilihat dari sudut pandang (point of view), kejelasan konsep, relefan dengan kurikulum, menarik minat siswa, menumbuhkan motivasi. Dengan itu dalam memilih buku teks pembelajaran harus memenuhi kriteria kelayakan. Badan Standar Nasional Pendidikan (BSNP) dalam Juwita dkk (2017: 64) mengemukakan bahwasannya terdapat kriteria mutu (standar) buku teks pelajaran yaitu : kelayakan isi/materi, kelayakan penyajian, kelayakan bahasa, kelayakan kegrafikan. Dari pendapat tersebut dapat disimpulkan bahwa buku teks yang layak digunakan dalam pembelajaran yaitu buku yang mempunyai empat kriteria kelayakan isi/materi, kelayakan penyajian, kelayakan bahasa, kelayakan kegrafikan.

Berdasarkan latar belakang tersebut, maka peneliti mengambil sampel 10 SD/MI yang meliputi SD Negeri 1 Purbalingga Lor, SD Negeri 2 Purbalingga Lor, SD Negeri 1 Purbalingga Kidul, SD Negeri 2 Wirasa, SD IT harapan Umat, MIM Wirasana, MIM Pesayangan, MI Cabang Purbalingga, MIM Kalikabong dan MI Istiqomah Sambas. Yang berjumlah keseluruhan buku teks ada 29 dengan kategori yang tergolong buku teks ada 21 sedangkan yang tidak tergolong ada 8 buku teks. Pentingnya kelayakan buku tematik di SD/MI khususnya kelas III sehingga akan dilakukan penelitian dengan judul "Analisis Kelayakan Buku Tematik Pada Muatan Pembelajaran Membaca Di Kelas III Sekolah Dasar/Madrasah Ibtidaiyah Di Kecamatan Purbalingga”.

\section{Metode Penelitian}

Penelitian ini menggunakan penelitian deskriptif kualitatif. Penelitian ini mendeskripsikan bagaimana kriteria kelayakan buku dalam pembelajaran membaca buku teks pelajaran kelas III SD/MI. Penelitian ini dilaksanakan pada di SD Negeri 1 Purbalingga Lor, SD Negeri 2 Purbalingga Lor, SD Negeri 2 Wirasa, SD Negeri 1 Purbalingga Kidul, MI Muhammadiyah Cabang, MI Muhammadiyah Wirasana, MI Muhammdaiyah Pesayangan, MI Istiqomah Sambas, dan MI Kalikabong. Waktu penelitian ini pada Bulan Mei sampai Bulan Juni 2021. Terdapat 2 sumber data dalam penelitian ini yaitu data sekunder dan data primer. Data primer merupakan data utama yang digunakan untuk mencari informasi dalam penelitian kualitatif. Data primer merupakan data yang diperoleh langsung dari tempat penelitian. Data primer dalam penelitian ini berupa Buku Teks Pelajaran Kelas III. Sedangkan data sekunder merupakan data yang digunakan untuk melengkapi data 
primer. Data sekunder dalam penelitian ini adalah kajian kepustakaan berupa buku dan artikel-artikel ilmiah yang memberikan informasi terkait penelitian ini.

Penelitian ini menggunakan teknik analisis data kualitatif menurut Miles and Hubermen (Sugiyono, 2017:337-338) yaitu data collection, data reduction, data display, dan conclusion drawing/verification.

Keabsahan data yang dilakukan peneliti kualitatif menggunakan triangulasih sumber. Menurut Wiliam dalam (Sugiono, 2010: 372) menjelaskan triangulasih dalam pengujian kredibilitas ini diartikan sebagai mengecek data dari sumber dengan cara kemudian berbagi waktu. Adapun jenis triangulasih yang meliputi triangulasih sumber, triangulasih teknik, dan triangulasih waktu. Triangulasih sumber merupakan untuk menguji kredibilitas data yang dilakukan untuk pengecekan data yang telah diperoleh meliputi beberapa sumber. Sumber yang digunakan untuk uji kredibilitas yaitu berasal dari buku teks pelajaran kelas III dan studi pustka.

\section{Hasil dan Pembahasan}

Berdasarkan telaah yang dilakukan oleh penelaah, maka dapat diperoleh hasil telaah yang berkaitan dengan kelayakan pada pembelajaran membaca yang ada dalam buku teks pelajaran kelas III SD/MI. Teknik pengumpulan data dilakukan dengan observasi, analisis teks dan studi Pustaka. Pengumpulan data diawali dengan mencari teori-teori dan kajian pustka yang berkaitan dengan standar kelayakan buku teks pada pembelajaran membaca yang ada dalam buku teks baik dalam buku elektronik atau BSE. Hal tersebut digunakan sebagai pedoman dalam menelaah buku teks pelajaran yang akan ditelaah.

\subsection{Buku Tematik Terpadu Kurikulum 2013 Tema 8 "Praja Muda Karana"}

- Telaah Kelayakan Kegarikaan

Hasil telaah kegrafikam terdiri atas 3 komponen yaitu kesesuaian ukuran buku yang dilihat dari standar ISO dari materi buku teks pelajaran, desain kulit buku teks pelajaran dan desain isi buku teks pelajaran. Ukuran dari buku ini 21,0 X 29,7. Ukuran tersebut sudah sesuai dengan standar ISO yaitu kertas A4. Komponen desain kulit buku terdapat tulisan "Kementrian Pendidikan dan Kebudayaan Republik Indonesia 2017" kemudian terdapat logo pendidikan. Tulisan dan logo memberikan informasi kepada pembaca bahwa buku ini dikeluarkan dari pemerintah. Terdapat logo Kurikulum 2013 edivisi revisi buku teks pelajaran 
disebelah kanan atas.

Judul terletak dibawah tulisan kementrian dan dibuat ukuran lebih besar dibandingkan dengan tulisan yang lain. Dibawah judul terdapat tulisan "Buku Tematik Terpadu Kurilum 2013”. Pada bagian bawah terdapat gambar ilustrasi dengan ukuran yang besar, dibagian bawah sebelah kanan terdapat "Buku Siswa SD/MI Kelas III" artinya buku tersebut buku pegangan siswa kelas III. Huruf pada tulisan menggunakan huruf "Baar Metanoia" warna yang digunakan pada kulit buku sudah sesuai dengan perpaduan warna sehingga lebih menarik siswa.

Desain komponen isi buku sudah sesuai, huruf yang digunakan pada bagaian isi buku sama dengan yang digunakan pada sampul buku "Baar Metanoia" dengan ukuran 12. Spasi dan margin yang digunakan sudah sesuai dengan standar. Gambar yang digunakan pada ilustrasi tidak mengganggu judul, teks, maupun halaman sehingga terlihat jelas. Tata letak dibagian paling atas dengan subjudul juga diletakkan di bagian atas. Nomor halaman pada bagian bawah kiri. Daya keterbacaan pada buku teks ini mudah untuk dipahami sehingga memudahkan siswa untuk memperlajari.

\subsection{Buku Pengayaan Tema 8 "Praja Muda Karana” Semester Genap}

- Telaah Kelayakan Kegrafikaan

Hasil telaah kelayakan kegrafikan pada buku tema ini terdiri dari 3 komponen yaitu kesesuaian ukuran buku dilihat dari standar IOS maupun dari materi dalam buku teks pelajaran, ukuran buku ini 22,3 X 29,9. Ukuran tersebut sudah sesuai dengan standar ISO yaitu ukuran A4. Komponen desain isi buku atau sampul buku terdapat tulisan pengarang buku dibawah pengarang buku terdapat penerbit dan digunakan sebagai buku pendamping Buku Tematik Tema 8 yang dikeluarkan oleh pemerintah seperti Buku Tema 8. Disamping penerbit terdapat logo kurikulum 2013.

Gambar ilustrasi memenuhi kulit buku, gambar ilustrasi dengan ukuran yang besar dan kontras warnya sudah sesuai. Gambar ilustrasi menggambarkan dari isi buku, dibawah ilustrasi terdapat judul buku "Praja Muda Karana" tulisan tersebut memberikan informasi kepada pembaca. Huruf pada tulisan menggunakan huruf “Arial Black". Warna yang digunakan dalam kulit buku ini sudah sesuai dengan kekontrasan sehingga siswa tertarik.

Komponen desain isi buku sudah sesuai, huruf yang digunakan pada bagaian isi buku menggunakan huruf "Arial” dengan ukuran 13. Spasi dan margin sudah 
sesuai dengan proposionalnya. Gambar ilustrasi pada teks bacaan sudah sesuai dan jelas tidak mengganggu judul, teks, maupun halaman sehingga tidak membingungkan. Tata letak judul terdapat dibagian halaman judul dan terletak bagian tengah serta dibagian kiri terdapat gambar ilustrasi, namun pada gambar ilustrasi masih menggunakan warna hitam dan putih sehingga kurang menarik. Subjudul diletakan dibagian tengah atas. Nomor halaman terletak pada bagian kanan bawah. Tulisan pada isi buku juga memiliki daya keterbacaan yang mudah untuk dipahami oleh siswa sehingga pada saat.

\subsection{Buku Forum Tema 4 "Kewajiban dan Hakku" Semester Ganjil}

- Telaah Kelayakan Kegrafikaan

Hasil telaah kegrafikan terdiri dari 3 komponen yaitu kesesuaian ukuran buku dilihat dari standar ISO maupun dari isi materi dalam buku teks pelajaran, desain kulit buku pada buku teks pelajaran, desain isi buku teks pelajaran. Ukuran dari buku ini 21,5 X 29,5. Ukuran tersebut sudah ISO yaitu ukuran A4. Ukuran buku tersebut sesuai dengan materi yang ada pada buku. Komponen desain kulit buku, sampul buku terdapat tulisan "Buku Pengayaan". Tulisan tersebut bertujuan untuk memberikan informasi kepada pembaca bahwa buku tersebut dikelurkan penerbit untuk siswa yang dapat digunakan untuk buku pendamping pembelajaran Tema 8 yang dikeluarkan dari pemerintah. Dibawahnya tertulis nama pengarangnya dan disampingnya logo kurikumkulum 2013.

Konsep desain isi buku sudah sangat sesuai, huruf yang digunakan pada bagian isi buku menggunakan huruf "Arial" dengan ukuran 13. Sapasi dan margin yang digunakan juga sudah sesuai dengan proposionalnya. Gambar ilustrasi yang terdapat pada bacaan sudah sesuai tidak mengganggu judul, teks, maupun halaman sehingga terlihat jelas dan tidak membingungkan. Tata letak judul terdapat dibagian halaman judul dan diletakan dibagian tengah serta judul diberikan tulisan yang tebal, gambar ilustrasi terletak dibagian kanan teks bacaan namun gambar ilustrasi tidak berwarna dan masih menggunkan warna hitam putih sehingga kurang menariksiswa. Subjudul diletakkan dibagian atas. Nomor halaman diletakan pada bagian bawah kiri.

\subsection{Buku Forum Tema 4 "Kewajiban dan Hakku" pegangan siswa}

- Telaah Kelayakan Kegrafikaan

kesesuain ukuran dari standar ISO maupun dari isi materi dalam buku teks pelajaran, desain kulit buku pada buku teks pelajaran. Ukuran pada buku ini 30,5 X 
$22 \mathrm{~cm}$. Ukuran terasebut sudah sesuai dengan ukuran standar ISO yaitu kertas A4. Ukuran tersebut sudah sesuai dengan isi materi yang ada pada buku. Komponen desain kulit buku, pada kulit buku atau sampul buku terdapat tulisan "FORUM aktif kratif inovatif' bertujuan untuk memberikan informasi kepada pembaca bahwa buku tersebut dikeluarkan oleh penerbit swasta yang digunakan sebagai buku pendamping pembelajaran. Disampingnya terdapat logo kurikum 2013 buku teks pelajaran.

Tata letak judul terdapat dibawah penerbit dan dibuat dengan ukuran tulisan yang kebih besar dibandingkan dengan tulisan yang lainya. Dibawah judul terdapat gambar ilustrasi yang sesuai dengan isi dari buku tersebut dengan kekontasan warna yang sesuai. Kemudian dibawah gambar ilustrasi terdapat nama pengarang kemudian dibawah pengarang terdapat kolom identitas siswa yang terdiri dari nama, kelas dan sekolah. Kemudian disamping sebelah kanan terdapat tulisan kelas dan tema yang sedang dipelajari. Tulisan pada sampul buku menggunakan "Arial Black". Warna yang digunakan pada sampul buku sudah sesuai sehingga dapat menarik siswa.

Komponen desain isi buku sudah sesuai, huruf yang digunakan pada bagian ini menggunakan “Arial Black” dengan ukuran 13, spasi yang digunakan sudah sesuai. Tata letak judul yang terdapat pada teks bacaan dibagian judul dan diletakkan ditengah. Bagian subjudul diletakkan pada bagian tengah atas. Nomor halaman terdapat pada bagian sebalah kanan bawah.

\subsection{Buku Tema 7 "Perkembangan Teknologi”" pegangan siswa}

- Telaah Kelayakan Kegrafikaan

Ukuran buku yang dilihat dari standar ISO, desain kulit buku pada buku teks pelajaran, desain isi buku. Ukuran pada buku ini 21,0 X 29,7. Ukuran tersebut sudah sesuai dengan ukuran kertas A4. Komponen kulit buku juga sudah sesuai denga isi buku. Pada buku tematik terdapat tulisan "Tim PUDSIKLAT JSIT Jawa Tengah" tulisan tersebut bertujuan untuk memberikan informasi penulis buku ini. Kemudian disampinya terdapat tulisan "JSIT INDONESIA" yang dikeluarkan penerbit swasta.

Tata letak judul terdapat bawah penulis buku dan dibawah penerbit dengan ukurang yang cukup besar dibandingkan dengan tulisan yang lainnya. Dibawah judul terdapat tulisan tema dan kemudian dibawah tulisan tema terdapat tulisan judul subjudul dari materi yang akan dipelajari. Kemudian dibawah tulisan subjudul terdapat gambar ilustrasi sebagai gambaran dari isi buku tematik ini. Dipojok 
sebelah kanan terdapat tulisan "Kelas III" bertujuan untuk memberikan informasi kepada pembaca. Tulisan pada kulit buku menggunakan “Arial Rounded MT Bold”. Warna yang digunakan untuk desain kulit buku sudah sesuai dengan perpaduan warna.

Komponen desain isi buku sudah sesuai, huruf yang digunakan juga sama seperti huruf yang digunakan pada sampul buku yaitu "Arial Rounded MT Bold" dengan ukuran huruf 12. Spasi dan margin yang digunakan sesuai dengan standar yang digunakan. Gambar ilustrasi tidak mengganggu judul teks maupun halaman sehingga tetap terlhat jelas. Tata letak judul terdapat dibagian judul dan diletkkan ditengah serta diberikan gambar ilustrasi. Gambar ilustrasi sudah menggunakan warna yang sesuai sehingga memberikan kesan seperti nyata. Pada bagian subjudul diletakkan dibagian atas. Nomor halaman diletakkan dibagian kanan bawah.

\section{Kesimpulan}

Hasil penelitian dari lima buku menunjukkan bahwa kualitas buku dilihat dari kriteria kelayakan kegrafikaan sudah sesuai dengan standar. Baik dilihat dari ukuran buku, warna desain buku dan gambar ilustrasi

\section{DAFTAR PUSTAKA}

Asri, H. Sahrul. (2017). Telaah Buku Teks Pegangan Guru Dan Siswa Pada Mata Pelajaran Bahasa Indonesia Kelas VII Berbasis Kurikulum 2013. Jurnal Ilmu Bahasa. 3(1): 70-82.

Juwita, Tita, Dkk. (2017). Analisis Kelayakan Buku Teks Siswa Kurikulum 2013 Pada Materi Sistem Pencernaan Kelas VII Untuk Digunakan Dalam Proses Pembelajaran Ditinjau Dari Relevansi Isi, Ketepatan, Dan Kompleksitas. Jurnal Bio Education. 2(1): 63-70.

Sugiyono. (2010). Metode Penelitian Pendidikan. Bandung: Alfabeta. 